\title{
Pearls \& Oy-sters: Leukoencephalopathy in critically ill patients with COVID-19
}

Hao Huang, MD, Hillary Eichelberger, MD, Monica Chan, MD, Eduard Valdes, MD, llya Kister, MD, Lauren Krupp, MD, Harold Weinberg, MD, Steven Galetta, MD, Jennifer Frontera, MD, Ting Zhou, MD, D. Ethan Kahn, DO, Aaron Lord, MD, and Ariane Lewis, MD

Neurology ${ }^{\circledR}$ 2020;95:753-757. doi:10.1212/WNL.0000000000010636

\section{Pearls}

- $\quad$ Coronavirus disease 2019 (COVID-19) can cause diffuse leukoencephalopathy.

- Although the pathophysiology of leukoencephalopathy due to COVID-19 is unclear, there are myriad possible mechanisms for this finding, including hypoxic-ischemic injury, microvascular thrombosis secondary to hypercoagulability, and endothelial damage.

\section{Oy-sters}

- Do not assume that critically ill patients with COVID-19 who are on sedation for a protracted period will be neurologically intact when sedation is discontinued and wears off.

- In critically ill patients with COVID-19 who have encephalopathy, before attributing prolonged coma to infection and toxic-metabolic conditions, obtain an MRI.

The neurologic manifestations of coronavirus disease 2019 (COVID-19) have been increasingly documented. ${ }^{1}$ However, severe encephalopathy with white matter changes on imaging has not been well-described. We present 4 patients with leukoencephalopathy following COVID-19 infection who were evaluated by the neurology team at New York University Langone Health-associated hospitals between April 2 and April 29, 2020. Select clinical data and laboratory values are found in table 1 and table e-1 (links.lww.com/WNL/B187), respectively. All 4 cases were positive for severe acute respiratory syndrome coronavirus 2 (SARS-CoV-2) nasopharyngeal PCR on admission.

\section{Case reports}

\section{Case 1}

A 49-year-old man with a history of type II diabetes mellitus and thymoma presented to the emergency department (ED) with 3 days of cough. He developed hypoxic respiratory failure and required endotracheal intubation. He was treated empirically with hydroxychloroquine, azithromycin, zinc, and tocilizumab. He required multiple sedative agents for ventilator dyssynchrony. Neurology was consulted on hospital day 30, 4 days after discontinuation of sedation, because of persistent unresponsiveness. On evaluation, his eyes were open, but he did not attend, follow commands, or move his extremities in response to stimulation. MRI showed diffuse T2/ fluid-attenuated inversion recovery (FLAIR) hyperintensities in the supratentorial white matter with diffusion restriction but no enhancement with gadolinium (figure, A-C). CSF studies were notable for elevated protein $(147 \mathrm{mg} / \mathrm{dL})$ without pleocytosis $(3$ cells $/ \mathrm{mL}$ ) and negative SARSCoV-2 PCR. His serum neuron- specific enolase level was $4.5 \mu \mathrm{g} / \mathrm{L}$ (reference range 3.7-8.9 g/L). Serum myelin oligodendrocyte glycoprotein antibody titer was $<1: 10$. His mental status improved, such that he was able to follow one-step commands and answer simple yes or no questions, on hospital day 41. His tracheostomy was decannulated on hospital day 51 and he was discharged to a rehabilitation facility on day 69.

\author{
Correspondence \\ Dr. Huang \\ hao.huang@nyulangone.org
}


Table 1 Clinical characteristics

\begin{tabular}{|c|c|c|c|c|}
\hline & Patient 1 & Patient 2 & Patient 3 & Patient 4 \\
\hline Age, y & 49 & 73 & 43 & 23 \\
\hline Sex & Male & Male & Male & Male \\
\hline $\begin{array}{l}\text { Timing of initial MRI } \\
\text { (hospital day) }\end{array}$ & 33 & 31 & 31 & 5 \\
\hline $\begin{array}{l}\text { Days between } \\
\text { symptom onset and } \\
\text { MRI }\end{array}$ & 36 & 34 & 38 & 9 \\
\hline $\begin{array}{l}\text { Days intubated } \\
\text { before MRI }\end{array}$ & 33 & 22 & 31 & 0 \\
\hline $\begin{array}{l}\text { Days on } \\
\text { vasopressors } \\
\text { before MRI }\end{array}$ & 27 & 12 & 7 & 0 \\
\hline $\begin{array}{l}\text { Lowest oxygen } \\
\text { saturation before } \\
\text { MRI, \% }\end{array}$ & 52 & 83 & 80 & 93 \\
\hline Days with MAP $<65$ & 6 & 2 & 6 & 0 \\
\hline $\begin{array}{l}\text { Lowest MAP before } \\
\text { MRI }\end{array}$ & 54 & 54 & 43 & 76 \\
\hline $\begin{array}{l}\text { Required dialysis } \\
\text { prior to MRI }\end{array}$ & Yes & Yes & Yes & No \\
\hline Sedation prior to MRI & $\begin{array}{l}\text { Dexmedetomidine, fentanyl, } \\
\text { ketamine, midazolam, propofol }\end{array}$ & $\begin{array}{l}\text { Dexmedetomidine, fentanyl, } \\
\text { midazolam, propofol }\end{array}$ & $\begin{array}{l}\text { Fentanyl, } \\
\text { hydromorphone, } \\
\text { ketamine, } \\
\text { midazolam, propofol, } \\
\text { cisatracurium }\end{array}$ & None \\
\hline $\begin{array}{l}\text { COVID-19 empiric } \\
\text { treatment }\end{array}$ & $\begin{array}{l}\text { Hydroxychloroquine, azithromycin, } \\
\text { zinc, tocilizumab }\end{array}$ & $\begin{array}{l}\text { Hydroxychloroquine, } \\
\text { azithromycin, tocilizumab, } \\
\text { nitazoxanide }\end{array}$ & $\begin{array}{l}\text { Hydroxychloroquine, } \\
\text { azithromycin, } \\
\text { nitazoxanide, } \\
\text { tocilizumab }\end{array}$ & $\begin{array}{l}\text { Hydroxychloroquine, } \\
\text { azithromycin }\end{array}$ \\
\hline $\begin{array}{l}\text { Immunosuppressive } \\
\text { treatment }\end{array}$ & IV methylprednisolone for 5 days & $\begin{array}{l}\text { Prednisone } 10 \mathrm{mg} \text { daily (long- } \\
\text { term medication), then } \\
\text { methylprednisolone } 40 \mathrm{mg} \text { for } 1 \\
\text { week, then hydrocortisone } 25 \mathrm{mg} \\
\text { every } 12 \text { hours for } 3 \text { days }\end{array}$ & No & No \\
\hline $\begin{array}{l}\text { Therapeutic } \\
\text { anticoagulation }\end{array}$ & Yes & Yes & Yes & Yes \\
\hline $\begin{array}{l}\text { Antimicrobial } \\
\text { treatment }\end{array}$ & $\begin{array}{l}\text { Amikacin, cefepime, clindamycin, } \\
\text { meropenem, micafungin, } \\
\text { vancomycin }\end{array}$ & $\begin{array}{l}\text { Cefepime, fluconazole, } \\
\text { levofloxacin, micafungin, } \\
\text { piperacillin- tazobactam, } \\
\text { vancomycin }\end{array}$ & $\begin{array}{l}\text { Ampicillin- } \\
\text { sulbactam, } \\
\text { ceftriaxone, } \\
\text { meropenem, } \\
\text { piperacillin- } \\
\text { tazobactam, } \\
\text { vancomycin }\end{array}$ & $\begin{array}{l}\text { Ampicillin- sulbactam, } \\
\text { ceftriaxone, piperacillin- } \\
\text { tazobactam, vancomycin }\end{array}$ \\
\hline $\begin{array}{l}\text { Neurologic } \\
\text { examination at } \\
\text { time of MRI }\end{array}$ & $\begin{array}{l}\text { Eyes open spontaneously, blink to } \\
\text { threat present, extraocular } \\
\text { movements intact, does not follow } \\
\text { commands, grimaces in response } \\
\text { to pain }\end{array}$ & $\begin{array}{l}\text { Eyes open to stimulation, pupils } \\
\text { reactive, does not track, grimaces } \\
\text { to pain }\end{array}$ & $\begin{array}{l}\text { Sedated, no response } \\
\text { to noxious } \\
\text { stimulation, no } \\
\text { brainstem reflexes }\end{array}$ & $\begin{array}{l}\text { Eyes open to noxious stimulation, } \\
\text { pupils reactive, gaze midline, no } \\
\text { blink to threat, extensor posturing } \\
\text { to noxious stimuli, plantar } \\
\text { extensor response }\end{array}$ \\
\hline $\begin{array}{l}\text { Outcome at time } \\
\text { of publication }\end{array}$ & Rehabilitation Facility & Deceased & Deceased & Deceased \\
\hline CSF studies & $\begin{array}{l}\text { WBC } 3 / \mu \mathrm{L} \text {, protein } 147 \mathrm{mg} / \mathrm{dL} \text {, } \\
\text { glucose } 62 \mathrm{mg} / \mathrm{dL}, \mathrm{PCR} \text { assay } \\
\text { negative SARS-CoV-2, oligoclonal } \\
\text { bands negative, CSF angiotensin- } \\
\text { converting enzyme } 1.7 \mathrm{U} / \mathrm{L} \text {, no flow } \\
\text { cytometry evidence of non-Hodgkin } \\
\text { lymphoma, no evidence of chronic } \\
\text { neuroinflammatory process }\end{array}$ & Not obtained & Not obtained & Not obtained \\
\hline
\end{tabular}

Abbreviations: COVID-19 = coronavirus disease 2019; ICU = intensive care unit; MAP = mean arterial pressure; SARS-CoV-2 = severe acute respiratory syndrome coronavirus 2; WBC = white blood cell count. 

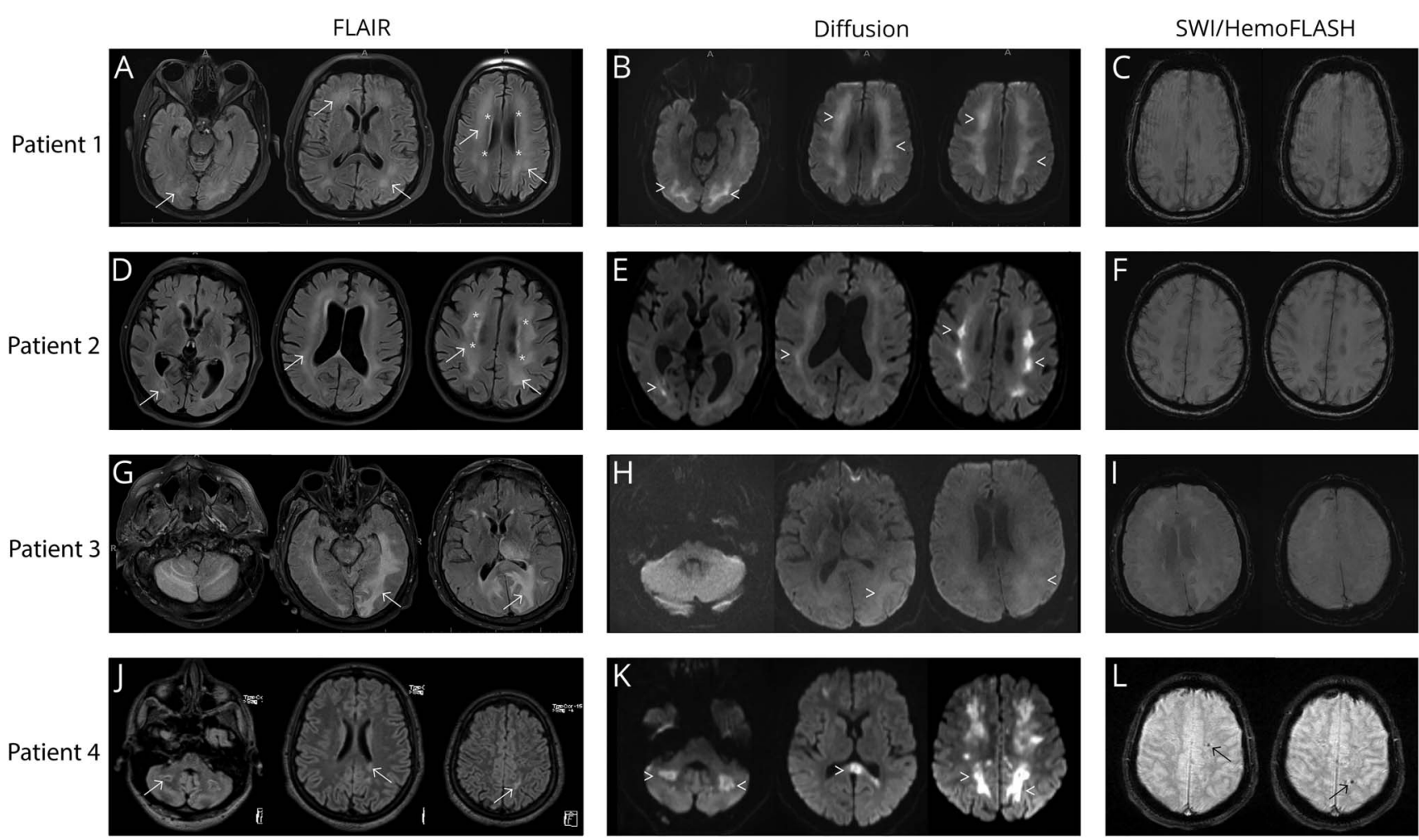

There are bilateral confluent areas of hyperintensity on T2 and fluid-attenuated inversion recovery (FLAIR) sequences (arrows; $A$, D, G, J), associated with diffusion restriction on diffusion-weighted imaging (arrowheads; B, E, H, K; apparent diffusion coefficient sequences with matching hypointensity are not shown). There are patchy areas of T2 and FLAIR hypointensity embedded in those lesions (asterisks; A, D). Susceptibility-weighted imaging sequences demonstrate no evidence of hemorrhage in patients 1 to $3(C, F, I)$ and rare foci of microhemorrhages in patient 4 on fast low angle shot gradient echo (HemoFLASH) (black arrows; L). MRI from patients 1 and 4 were performed with and without gadolinium contrast, but there is no associated gadolinium contrast enhancement or evidence of venous sinus thrombosis (postcontrast sequences are not shown). Twenty-three days after the initial MRI, patient 1 had a repeat MRI brain (not shown here) with stable findings, including confluent T2 lesions and restricted diffusion.

\section{Case 2}

A 73-year-old man with a history of coronary artery disease, Crohn disease, and prostate cancer with metastasis to the spine presented after 1 day of dyspnea, fever, and diarrhea. On hospital day 9, he was intubated for hypoxic respiratory failure. He received empiric treatment with hydroxychloroquine, azithromycin, tocilizumab, and nitazoxanide. He required multiple sedative agents throughout his hospital course, which were discontinued on hospital day 19, but he continued to be unresponsive. On neurologic examination, he had spontaneous eye opening with intact pupillary light reflex and grimaced to noxious stimuli in all extremities. MRI of the brain showed confluent white matter hyperintensities in the frontoparietal and temporo-occipital lobes with associated diffusion restriction (figure, D-F). Another brain MRI was performed 23 days later and showed stable findings. He made no improvement in neurologic function and died on hospital day 60,2 days after he was transitioned to comfort care.

\section{Case 3}

A 43-year-old morbidly obese man presented with 7 days of progressive dyspnea, cough, fever, and generalized malaise. He was intubated for hypoxic respiratory failure and treated empirically with hydroxychloroquine, azithromycin, and tocilizumab. He required multiple sedative agents and neuromuscular blockade for ventilator dyssynchrony. On hospital day 29, he had 3 generalized tonic-clonic seizures. Neurologic examination revealed a lack of response to external stimuli and absent brainstem reflexes. MRI of the brain showed confluent T2/ FLAIR hyperintensities involving the supratentorial and infratentorial white matter with associated diffusion restriction (figure, G-I). He showed no neurologic improvement and died of multiorgan failure on hospital day 38 .

\section{Case 4}

A previously healthy 23-year-old man presented with 5 days of fever and encephalopathy. In the ED, he was somnolent, and his initial plasma glucose level was $1,384 \mathrm{mg} / \mathrm{dL}$. Metabolic acidosis resolved within 24 hours, but he remained obtunded. He was treated with hydroxychloroquine and azithromycin. Neurologic examination was notable for unresponsiveness, extensor posturing to noxious stimulation in all extremities, and bilateral plantar extensor responses. EEG showed diffuse background slowing, but no seizures. MRI showed confluent T2/FLAIR hyperintensities with associated areas of diffusion restriction, but no enhancement with gadolinium, and 2 foci 
of microhemorrhages (figure, J-L). On hospital day 5, he required endotracheal intubation for hypoxic respiratory failure. He died on hospital day 10 of multiorgan failure.

\section{Discussion}

This case series highlights the potential for critically ill patients with COVID-19 to develop leukoencephalopathy that may only become clinically evident after sedation is withdrawn. Based on our current understanding of the pathophysiology of COVID-19, we discuss the possible mechanisms that could lead to leukoencephalopathy in these patients.

Patients with COVID-19 often develop a hypercoagulable state, as demonstrated by elevated D-dimer. ${ }^{1}$ Although neuropathologic data in patients with COVID-19 are lacking, it is probable that these patients develop microvascular thromboses in the brain. ${ }^{2}$ There are areas of low T2/FLAIR signal at the center of many of the deep lesions in 2 cases, which may represent deoxyhemoglobin in dilated veins as a result of thrombosis in the deep venous system, but there is absence of enhancing transcerebral or medullary veins in the postcontrast sequences in the other cases. ${ }^{3,4}$

Prolonged shock and refractory hypoxia in severe disease states can lead to cerebral hypoxic and ischemic injury, which likely also plays an important role in the development of these white matter changes. This can result in a diffuse leukoencephalopathy similar to delayed posthypoxic leukoencephalopathy, ${ }^{5}$ which would explain why these white matter changes are predominantly seen in watershed areas, though it is worth noting that the distribution of white matter changes is different from that typically seen in hypoxic brain injury.

Because elevated serum cytokine levels and inflammatory markers are hallmarks of severe COVID-19, ${ }^{1}$ these white matter changes could be the consequence of maladaptive systemic immune responses, as seen in acute necrotizing encephalopathy (ANE). However, our cases lack the symmetric thalamic lesions that are characteristic of ANE. ${ }^{6}$ The findings of punctate microhemorrhages in patient 4 prompted consideration of acute hemorrhagic leukoencephalitis (AHLE), but a more significant amount of hemorrhage would be expected with AHLE. ${ }^{7}$ Acute disseminated encephalomyelitis (ADEM) could also be considered, but the clinical course and MRI findings in these cases are highly atypical for ADEM, which is characterized by asymmetric poorly demarcated lesions that occasionally show restricted diffusion. ${ }^{8}$

The SARS-CoV-2 virus enters cells via angiotensin-converting enzyme II, which is expressed in the brain's endothelial cells. ${ }^{1}$ Damage to the endothelial cells can lead to dysautoregulation of the cerebral vasculature resulting in capillary leak and further exacerbation of cerebral ischemia, creating a clinical picture that is akin to posterior reversible encephalopathy syndrome. Another possible explanation for this leukoencephalopathy is direct CNS invasion by the virus causing encephalitis, though direct evidence of encephalitis secondary to SARS-CoV-2 is lacking.

Finally, leukoencephalopathy may be due to toxic metabolic causes such as uremia and electrolyte disturbances. However, brain lesions associated with uremic encephalopathy preferentially involve the basal ganglia, and usually do not result in confluent bilateral white matter lesions. ${ }^{5}$ Extreme acute hyperglycemic and hyperosmotic states can lead to white matter lesions, ${ }^{9}$ but these conditions were only present in patient 4 .

The small number of cases, absence of serial imaging and CSF results on all patients, and lack of histopathologic data limit our understanding of these findings.

A growing body of evidence suggests that SARS-CoV-2 has multiple deleterious effects on the CNS through various mechanisms. ${ }^{1}$ Our case series highlights the potential for patients with severe cases of COVID-19 to develop diffuse white matter disease, which appears to be distinct from known diagnoses, and may represent a novel radiologic pattern. In the critically ill COVID-19 population, it is important to avoid prematurely ascribing encephalopathy or coma to toxicmetabolic or other systemic causes, and to consider the possibility of structural brain damage. Longitudinal follow-up studies and histologic studies of brain tissue could help provide further insight.

\section{Study funding}

No targeted funding reported.

\section{Disclosure}

The authors report no disclosures relevant to the manuscript. Go to Neurology.org/N for full disclosures.

\begin{tabular}{|c|c|c|}
\hline Name & Location & Contribution \\
\hline $\begin{array}{l}\text { Hao Huang, } \\
\text { MD }\end{array}$ & $\begin{array}{l}\text { NYU Langone } \\
\text { Health, New } \\
\text { York, NY }\end{array}$ & $\begin{array}{l}\text { Designed and conceptualized study, } \\
\text { analyzed the data, drafted and } \\
\text { revised the manuscript for } \\
\text { intellectual content, major role in } \\
\text { the acquisition of data }\end{array}$ \\
\hline $\begin{array}{l}\text { Hillary } \\
\text { Eichelberger, } \\
\text { MD }\end{array}$ & $\begin{array}{l}\text { NYU Langone } \\
\text { Health, New } \\
\text { York, NY }\end{array}$ & $\begin{array}{l}\text { Designed and conceptualized study, } \\
\text { analyzed the data, drafted and } \\
\text { revised the manuscript for } \\
\text { intellectual content, major role in } \\
\text { the acquisition of data }\end{array}$ \\
\hline $\begin{array}{l}\text { Monica Chan, } \\
\text { MD }\end{array}$ & $\begin{array}{l}\text { NYU Langone } \\
\text { Health, New } \\
\text { York, NY }\end{array}$ & $\begin{array}{l}\text { Design and conceptualized study, } \\
\text { analyzed the data, drafted and } \\
\text { revised the manuscript for } \\
\text { intellectual content, major role in } \\
\text { the acquisition of data }\end{array}$ \\
\hline $\begin{array}{l}\text { Eduard } \\
\text { Valdes, MD }\end{array}$ & $\begin{array}{l}\text { NYU Langone } \\
\text { Health, New } \\
\text { York, NY }\end{array}$ & $\begin{array}{l}\text { Designed and conceptualized study, } \\
\text { analyzed the data, drafted and } \\
\text { revised the manuscript for } \\
\text { intellectual content, major role in } \\
\text { the acquisition of data }\end{array}$ \\
\hline
\end{tabular}


Appendix (continued)

\begin{tabular}{|c|c|c|}
\hline Name & Location & Contribution \\
\hline $\begin{array}{l}\text { Ilya Kister, } \\
\text { MD }\end{array}$ & $\begin{array}{l}\text { NYU Langone } \\
\text { Health, New } \\
\text { York, NY }\end{array}$ & $\begin{array}{l}\text { Analyzed the data, revised the } \\
\text { manuscript for intellectual content }\end{array}$ \\
\hline $\begin{array}{l}\text { Lauren } \\
\text { Krupp, MD }\end{array}$ & $\begin{array}{l}\text { NYU Langone } \\
\text { Health, New } \\
\text { York, NY }\end{array}$ & $\begin{array}{l}\text { Analyzed the data, revised the } \\
\text { manuscript for intellectual content }\end{array}$ \\
\hline $\begin{array}{l}\text { Harold } \\
\text { Weinberg, } \\
\text { MD }\end{array}$ & $\begin{array}{l}\text { NYU Langone } \\
\text { Health, New } \\
\text { York, NY }\end{array}$ & $\begin{array}{l}\text { Analyzed the data, revised the } \\
\text { manuscript for intellectual content }\end{array}$ \\
\hline $\begin{array}{l}\text { Steven } \\
\text { Galetta, MD }\end{array}$ & $\begin{array}{l}\text { NYU Langone } \\
\text { Health, New } \\
\text { York, NY }\end{array}$ & $\begin{array}{l}\text { Analyzed the data, revised the } \\
\text { manuscript for intellectual content }\end{array}$ \\
\hline $\begin{array}{l}\text { Jennifer } \\
\text { Frontera, MD }\end{array}$ & $\begin{array}{l}\text { NYU Langone } \\
\text { Health, New } \\
\text { York, NY }\end{array}$ & $\begin{array}{l}\text { Analyzed the data, revised the } \\
\text { manuscript for intellectual content }\end{array}$ \\
\hline $\begin{array}{l}\text { Ting Zhou, } \\
\text { MD }\end{array}$ & $\begin{array}{l}\text { NYU Langone } \\
\text { Health, New } \\
\text { York, NY }\end{array}$ & $\begin{array}{l}\text { Analyzed the data, revised the } \\
\text { manuscript for intellectual content }\end{array}$ \\
\hline $\begin{array}{l}\text { D. Ethan } \\
\text { Kahn, DO }\end{array}$ & $\begin{array}{l}\text { NYU Langone } \\
\text { Health, New } \\
\text { York, NY }\end{array}$ & $\begin{array}{l}\text { Analyzed the data, revised the } \\
\text { manuscript for intellectual content }\end{array}$ \\
\hline $\begin{array}{l}\text { Aaron Lord, } \\
\text { MD }\end{array}$ & $\begin{array}{l}\text { NYU Langone } \\
\text { Health, New } \\
\text { York, NY }\end{array}$ & $\begin{array}{l}\text { Designed and conceptualized study, } \\
\text { analyzed the data, revised the } \\
\text { manuscript for intellectual content, } \\
\text { major role in the acquisition of data }\end{array}$ \\
\hline
\end{tabular}

Appendix (continued)

\begin{tabular}{lll}
\hline Name & Location & Contribution \\
\hline $\begin{array}{lll}\text { Ariane Lewis, } \\
\text { MD }\end{array}$ & $\begin{array}{l}\text { NYU Langone } \\
\text { Health, New } \\
\text { York, NY }\end{array}$ & $\begin{array}{l}\text { Designed and conceptualized } \\
\text { study, analyzed the data, } \\
\text { revised the manuscript for } \\
\text { intellectual content, major } \\
\text { role in the acquisition of data }\end{array}$ \\
\end{tabular}

\section{References}

1. Zubair AS, McAlpine LS, Gardin T, Farhadian S, Kuruvilla DE, Spudich S. Neuropathogenesis and neurologic manifestations of the coronaviruses in the age of coronavirus disease 2019: a review. JAMA Neurol Epub 2020 May 29.

2. Valderrama Valdes E, Humbert K, Lord A, Frontera J, Yaghi S. Severe acute respiratory syndrome coronavirus 2 infection and ischemic stroke. Stroke 2020;51: e124-e127.

3. Friedman DP. Abnormalities of the deep medullary white matter veins: MR imaging findings. AJR Am J Roentgenol 1997;168:1103-1108.

4. Sohn CH, Lee HP, Park JB, et al. Imaging findings of brain death on 3-tesla MRI. Korean J Radiol 2012;13:541-549.

5. Bathla G, Hegde AN. MRI and CT appearances in metabolic encephalopathies due to systemic diseases in adults. Clin Radiol 2013;68:545-554

6. Wong AM, Simon EM, Zimmerman RA, Wang HS, Toh CH, Ng SH. Acute necrotizing encephalopathy of childhood: correlation of MR findings and clinical outcome. AJNR Am J Neuroradiol 2006;27:1919-1923.

7. Gibbs WN, Kreidie MA, Kim RC, Hasso AN. Acute hemorrhagic leukoencephalitis: neuroimaging features and neuropathologic diagnosis. J Comput Assist Tomogr 2005;29:689-693

8. Fugate JE, Rabinstein AA. Posterior reversible encephalopathy syndrome: clinical and radiological manifestations, pathophysiology, and outstanding questions. Lancet Neurol 2015;14:914-925

9. Barrot A, Huisman TA, Poretti A. Neuroimaging findings in acute pediatric diabetic ketoacidosis. Neuroradiol J 2016;29:317-322.

\section{Subspecialty Alerts by E-mail!}

Customize your online journal experience by signing up for e-mail alerts related to your subspecialty or area of interest. Access this free service by clicking on the "My Alerts" link on the home page. An extensive list of subspecialties, methods, and study design choices will be available for you to choose from-allowing you priority alerts to cutting-edge research in your field!

\section{Call for Abstracts-Submit Your Best Science by October 19}

Visit AAN.com/21Abstracts before October 19 to submit your breakthrough research to the best platform for getting your work noticed by your neurology peers from around the globe-the 2021 AAN Annual Meeting, set for April 17-22. Abstracts will be accepted in all subspecialties and career levels for either virtual or in-person presentation. Gain exposure for your work with a chance to have your research picked up by major media outlets around the globe, including the New York Times, USA Today, CNN, and more! 


\section{Neurology}

Pearls \& Oy-sters: Leukoencephalopathy in critically ill patients with COVID-19

Hao Huang, Hillary Eichelberger, Monica Chan, et al.

Neurology 2020;95;753-757 Published Online before print August 11, 2020

DOI 10.1212/WNL.0000000000010636

This information is current as of August 11, 2020

\begin{tabular}{|c|c|}
\hline $\begin{array}{l}\text { Updated Information \& } \\
\text { Services }\end{array}$ & $\begin{array}{l}\text { including high resolution figures, can be found at: } \\
\text { http://n.neurology.org/content/95/16/753.full }\end{array}$ \\
\hline References & $\begin{array}{l}\text { This article cites } 8 \text { articles, } 0 \text { of which you can access for free at: } \\
\text { http://n.neurology.org/content/95/16/753. full\#ref-list- } 1\end{array}$ \\
\hline Citations & $\begin{array}{l}\text { This article has been cited by } 1 \text { HighWire-hosted articles: } \\
\text { http://n.neurology.org/content/95/16/753.full\#\#otherarticles }\end{array}$ \\
\hline Subspecialty Collections & $\begin{array}{l}\text { This article, along with others on similar topics, appears in the } \\
\text { following collection(s): } \\
\text { Coma } \\
\text { http://n.neurology.org/cgi/collection/coma } \\
\text { Critical care } \\
\text { http://n.neurology.org/cgi/collection/critical_care } \\
\text { MRI } \\
\text { http://n.neurology.org/cgi/collection/mri } \\
\text { Other cerebrovascular disease/Stroke } \\
\text { http://n.neurology.org/cgi/collection/other_cerebrovascular_disease_st } \\
\text { roke }\end{array}$ \\
\hline Permissions \& Licensing & $\begin{array}{l}\text { Information about reproducing this article in parts (figures,tables) or in } \\
\text { its entirety can be found online at: } \\
\text { http://www.neurology.org/about/about_the_journal\#permissions }\end{array}$ \\
\hline Reprints & $\begin{array}{l}\text { Information about ordering reprints can be found online: } \\
\text { http://n.neurology.org/subscribers/advertise }\end{array}$ \\
\hline
\end{tabular}

Neurology ${ }^{\circledR}$ is the official journal of the American Academy of Neurology. Published continuously since 1951, it is now a weekly with 48 issues per year. Copyright @ 2020 American Academy of Neurology. All rights reserved. Print ISSN: 0028-3878. Online ISSN: 1526-632X.

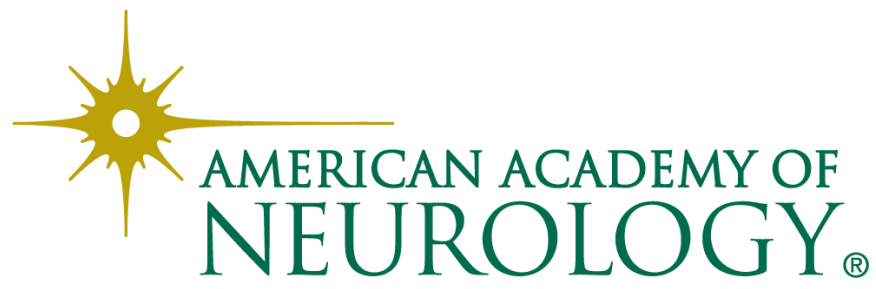

